Andrews University

Digital Commons @ Andrews University

Master's Theses

Graduate Research

1978

\title{
A Feasibility Study for the Development of a Natural Foods Restaurant in Tri-Cities, Washington
}

Millie Marrie Kurtz

Andrews University

Follow this and additional works at: https://digitalcommons.andrews.edu/theses

Part of the Education Commons, and the Food and Beverage Management Commons

\section{Recommended Citation}

Kurtz, Millie Marrie, "A Feasibility Study for the Development of a Natural Foods Restaurant in Tri-Cities, Washington" (1978). Master's Theses. 173.

https://dx.doi.org/10.32597/theses/173

https://digitalcommons.andrews.edu/theses/173

This Thesis is brought to you for free and open access by the Graduate Research at Digital Commons @ Andrews University. It has been accepted for inclusion in Master's Theses by an authorized administrator of Digital Commons@ Andrews University. For more information, please contact repository@andrews.edu. 


\title{
A.ESTRACT OF GRADUATE STUDENT RISEARCH \\ Thesis
}

\author{
Andrews University \\ Department of Education
}

\begin{abstract}
Title: A STUDY TO DETERMINE THE FEASIBILIYY OF DEVELOPJNG A NATURAL FOODS RESTAURANT IN TRI-CITIES, WASHINGTON

Name of researcher: Millie Marrie Kurtz

Name and title of faculty adviser: Fonda L. Chaffee, Ph.D., Chairperson, Department of Home Economics
\end{abstract}

Date completed: Decemider 1978

\section{Problem}

American consumers are eating more and more of their meals outside the home. Americans are also becoining nore diet conseious, and the Select Committee on Nutrition and Human Needs (Hiw) has encouraged restaurant managers to consider their impact on the nation's health. The purpose of this study was to survey the estingout habits and preferences of residents in three adjacent cities in southeastern Washington (Pasco, Richland, and Kennewick), and determine the potential acceptance of a natural foods restaurant in this Tri-City area. 


\section{Method}

A random sample of Tri-City residents was selected and interviewed by telephone. The telephone survey gave a high response level with minimal probing through a structured questionnaire that provided data concerning eating-out habits and interest in natural foods.

Twenty-three interviewers made 439 telephone contacts during a ten-day period from November 10-20, 1978. Four nundred and six responses were sufficiently clear for the purposes of this study. These were computer tabulated and compared with national statistics and trends.

\section{Results}

The results of this study showed that the majority of TriCity residents enjoyed eating out and did so about 58 percent of the time. They spent an average of $\$ 4.27$ per meal and usually traveled less than five miles to a restaurant. Quality and atmosphere was considered the most important features of restaurant service. A majcrity of the interviewees indicated they would patronize a natural foods restaurant. Preferred foods were fresh salads (fruit or vegetable), homemade soups, and fresh baked breads. New or unusual food items would not be readily accepted.

\section{Conclusions}

There is a potential market in the Tri-City area for a natural foods restaurant with emphasis on quality of food and service. It should be located within a three to five mile radius of the upper income residential area housing relatively young (25-34 years old) 
heads of household.

An increasing national trend for eating meals outside the home does not always coincide with an interest in natural foods.

Consequently, every potential location for a natural foods restaurant should be surveyed independently. 
Andrews University

School of Gräduate Studies

A FEASIBILITY STUDY FOR THE DEVELOPMENT

OF A NATURAI FOODS RESTAURANT

IN TRI-CITIES, WASHIVGTON

\section{A Thesis}

Presented in Partial Fulfillment

of the Requirements for the Degree

Master of Arts

by

Millie Marrie Kurtz

December 1978 
A FEASTBILITY STUDY FOR THE DEVELOPMENT OF A NATURAL FOODS RESTAURANT

IN TRI-CITIES, WASHINGTON

a thesis presented

in partial fulfillment of the requirements

for the degree

Master of Arts

by

Millie Marrie Kurtz

AFPROVAL BY THE COMMITTEE

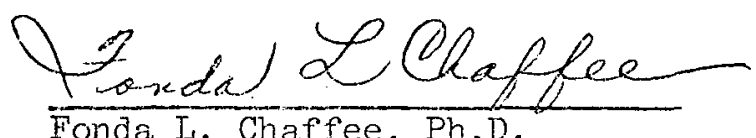

Chairperson Department Home Economics Andrews University

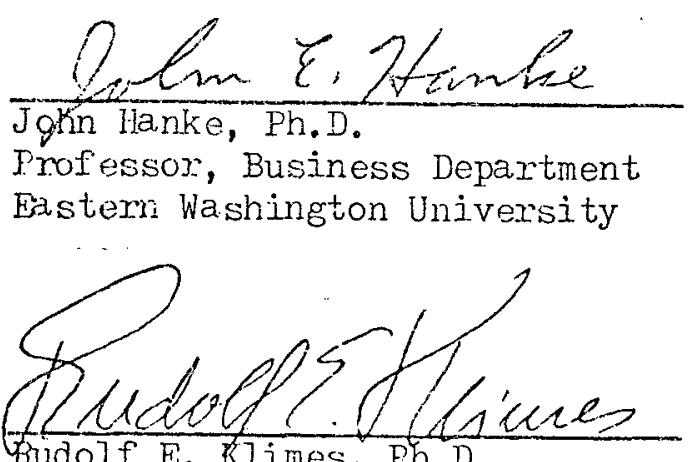

Tudolf E. Rlimes, Ph.D.

April 15, 1979

Professor Educational Administration Andrews University 
TABLE OF CONTENTS

LIST OF TABLES . . . . . . . . . . . . . v

ACKNOWLEDGEIVETTS. . . . . . . . . . . . . . vii

Chapter

I. RATIONALE FOR THE STUDY . . . . . . . . . I

Overview of the Problem ........... I

Significance of the Problem . . . . . . . . 3

Statement of the Problem ......... 4

Purpose ............... . 4

Ancillary Questions........... 5

Iinitations . . . . . . . . . . . 5

Definition of Texms ........ . 6

II. REVIWW OF RELATED LITERATURE . . . . . . . . 7

Trends in Amerjcan Food Expenditure . . . . ?

Significant factors . . . . . . . . 7

Income . . . . . . . . . . . . ?

Household size ............ . 9

Place of residence . . . . . . . . 9

Age of family head . . . . . . . . . 12

Trends in Health and Nutrition . . . . . . 12

Trends in The Festaurant Industry .. . . . . 14

Natural foods............. . 14

Sales volume ncrease... . . . . 16

Risk potential . . . . . . . . . 18

III. METHODS . . . . . . . . . . . 20

Locale . . . . . . . . . . . 20

Geographical ............ 20

Population . . . . . . . . . 20

Resources ............. 21

Financial base .......... 23

Shopper mobility .......... 24

Competition ............ 24

Sample Selection ........... 25 
Deta Collection ........... 26

Method .............. 26

Questionnaire......... 26

Survey method............. 28

Lata Treatment. . . . . . . . . . 29

IV. FINDINGS AND DISCUSSION . . . . . . . . 3 .

Findings .............. 31

Discussion ............. 44

V. CONCIUSIONS .................. 49

APPENDTX . . . . . . . . . . . . . 52

BIBLIOGRAPHY .............. 61 
1. Food Expenditures as a Proportion of lotal After-Tax Income (NationaI Estimates) . . . . . . . 8

2. Per Capita Weekly Food Expenditures per Income Level. 10

3. Per Capita Weekly Food Expenditures by Household Size ...................... 11

4. Per Capita Weekly Food Expenditures by Age of Household Head . . . . . . . . . . . 13

5. Ranking of Reasons for Making Decisions about Food. : 15

6. Pacific Coast Retail Trade Eating and Drinking. Establishments, 1977 . . . . . . . . . . . 17

7. Population Statistics for the Tri-Cities . . . . 21

8. Tri-City Retail Sales.............. 23

9. Tri-City Shopper Mobility . . . . . . . . . 24

10. Tri-City Total Sample... . . . . . . . 31

11. Frequency of Fating Out... . . . . . . . 32

12. Eating-Out History . . . . . . . . . . 33

13. Types of Eating Places Patronized . . . . . . . 34

14. Distance Traveled to Eat out . . . . . . . 35

15. Important Features of Restaurant Food-Service . . . 36

16. Favorite Ethnic Foods . . . . . . . . . . 37

17. Types of Eating Places Needed in Tri-Cities . . . 38

18. Predicted Patronage of a Natural Foods Restaurant . . 39

19. Favorite Natural Foods . . . . . . . . 40

20. Age of Family Head. . . . . . . . . . . . . 4 I 
21. Average Yearly Family Income . . . . . . . . 42

22. Education Level of Family Head .... . . . . 43

23. Family Size . . . . . . . . . . . . 44

24. Compilation of Demographic Data for a Select

Group of Tri-City Residents . . . . . . . 48 


\section{ACKNOWLEDGEMENTS}

I would like to acknowledge the following individuals without whose help this thesis and the completion of my masters program would never have been a reality:

To the members of my committee, Dr. Fonda. Chaffee, my major professor; Dr. John Hanke of Eastern Washington University: who helped me develop the survey tool; and Dr. Rudolf Klimes.

To Dr. Lynãon Furst, analyst, and Frank Clark, who gave assistance with data processing; to the interviewers whose service made possible the collection of data; and to the typist, Ginger Small.

To my husband Irvin and children Kathie, Richard, and Julie who deserve a very special thanks for their support and encouragement.

To my professional associate of 30 years, Clinton A. Wall, who encouraged me to further achievement. 


\section{CHAPTER I}

\section{RATIONAIE FOR 'THE STUDY}

The future looks bright for the restaurant industry, if current trends contjnue. "For every two meals consumed at home, Americans eat one meal outside the home ... And some industry seers predict that by 1980 consumers may be oating half of their meals away from home" (Eagen \& Cingolani, 1977).

The basic reasons for this trend are smaller family size, more women working outside the home, and more aisposable income. It is also interesting to note that time is of much more importance than money to the current generation. According to Blackwell (1977), demands on leisure time are increasing rapidly as is the availability of funds to spena on leisure time activities-making it possible to predict that the most popular products of the future will have either time saving or time enriching characteristics.

\section{Overview of the Problem.}

What this means for the restauranteur is that fast food service is in--for increasing leisure hours, but relaxed dining is also in-for enriching leisure time. This requires much more specialization for the industry than was previously required for the traditional restaurant service. It is difficult 
to incorporate speed into a relaxed dining atmosphere without disturbing the evening-out experience for the diner. Eating out is becoming more and more a social experience--a way to be with other people--to satisfy the emotional need for togetherness as much as it is a way to satisfy the physical need for food. Besides that, consumers are bored--they are searching for novelty, change, and escape (BIackwell, 1977).

Some independent restauranteurs have endeavored to meet this challenge by broadening their menu selection. to meet the demand for more variety, but spiraling food and labor costs have forced many of them to adapt the big chain's limited menu of hamburger, milkshakes, and french fries.

A second challenge facing the industry today is the increasing evidence of the linkage between the American diet and death-causing diseases. Research has show that "six of the ten leading causes of death in the United States have been Iinked to our diet" (Dietary Goals for the United States, 1977). A deep concern for this situation led the government to select a committee in 1977 to develop a set of dietary goals for the nation. This committee called "the Select Committee on Nutrition and Human Needs" encouraged among other things that those involved in growing, preparing, and processing foods give new considerations to the impact of their decisions on the nation's health.

This solemn admonition from the government plus the increase in meals consumed outside the home places a far greater responsibility on the restaurant manager today than when "an 
eighteenth century vendor hawked his sour as 'restaurants' (magical restorative) (Eagen \& Cingolanj, 1977).

Winikoff (1977), in a press release concerning the implications of dietary goals, stated,

That people learn their patterns of diet not only from the family and its sociocultural background, but from what is promoted both formally through advertising and informally through general availability in schools, restaurants, supermarkets and so forth. (p. 5)

So far the enphasis on hoalth and nutrition has done very little for the consumer in terms of practical application. The public has become much more aware of sound nutritional principles, as was demonstrated recently by a Harris Poll conducted for Mount Sinai Hospital in Chicago, but there still remains the age old disparity between what people know they should do and what they do. On the one hand they are told to at a better diet, while on the other hand they are encouraged through bombarding television commercials, vivid magazine ads, and market availability to purchase and consume nore items than are needed for nutrition and in some cases foods which are unhealthful.

\section{Significance of the Problem}

Since interest is being shown among consumers nationwide for a more healthful diet, it appears that it would be advisable for the restaurant industry to accomodate to the trend by adapting its normal fare to meet these demands.

A group of business persons in the Tri-Cities Washington 
area is interested in developing a natural foods restaurant to make available to residents a more nutritious meal service. However, i.t takes more than interest to succeed. The restaurant business is risky. In fact it has one of the highest rates of failure in the business world. It is estimated that for every new facility to open its doors, one half will close before the end of the first year of business (SBA, 1973).

\section{Statement of the Problem}

This study has been stimulated by the increasing focus nationwide on healthful living and concurrent relationship to dietary practices. It appears there is a need for vegetarian restaurants but there is a lack of feasibility studies to justify the establishment of such food systems. The problem to be studied is the feasibility of developing a natural foods restaurant in one specific area, namely, the Tri-Cities, Washingtor.

\section{Purpose}

The purpose of this study was seen as the planning and. implementing of a survey to ascertain the interest in and the Iinancial soundness of establishing a natural foods restaurant. Specifically, the purpose of the study was to:

1. Survey the eating-out habits of the area residents

2. Survey the food preferences of the area residents

3. Survey financial spending patterns when residents eat out

4. Survey the potential interest in a natural foods restaurant 
5. Tentatively forecast the success potential for establishing a natural foods restaurant in the Tri-Cities area.

\section{Ancillary Questions}

Ancillary questions to be examined are:

1. What is the demographic data as to age, income level, and so forth, of immediate population?

2. What distance would they travel?

3. What feature or features are most important to them?

4. Would Tri-City residents prefer a restaurant specializing in natural foods or a restaurant that features natural foods along with the normal fare?

5. What percentage of Tri-City residents are vegetarians?

6. What percentage have eaten in a natural foods restaurant?

\section{Limitations}

The population of this study will be limited to a random sampling of I'ri-City, Washington residents. The findings will be representative of the population studied, but the application cannot be generalized to the population at large.

A telephone survey is limited to the extent there will be variations of response due to the variation of interviewing techniques an personality differences among interviewers. 
Definition of Terms

For the purpose of this research, the following definitions will be used throughout the study:

$$
\begin{aligned}
& \text { Natural foods - non-flesh foods oriented toward } \\
& \text { health, simply prepared with a minimum amount of } \\
& \text { refining and processing } \\
& \text { Tri-cities -- Fasco, Kennewick, Richland, Washington } \\
& \text { Natural foods restaurant -- serving "natural foods" } \\
& \text { as described above. }
\end{aligned}
$$

It is important for anyone considering the establishment of a restaurant to be aware of the trends in the industry. Chapter II was developed as review of literature to discover these trends. 


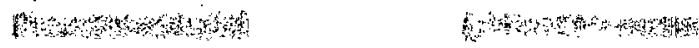

CHAPTER II

REVIEW OF RELATED LITERATURE

The restaurant as a food system in modern society is a well-established institution among business organizations of the world. There are varied restaurant styles each designed to meet the needs of a particular segment of the population, but for purposes of this study, attention is centered on the natural foods restaurant. The review of literature focused on three related areas: (1) trends in American food expenditure, (2) trends in health and nutrition, and (3) trends in the restaurant industry.

Trends in American Food Expenditure

Significant factors. According to a report by Rogers and Green (1978), the four most significant factors in determining patterns of food expenditure are: (1) income, (2) household size, (3) place of residence, (4) age of family head.

Income. Findings based on a national consumer expenditure survey of 23,000 households inaicated that the average American family income has increased considerably in recent years. In 1960 the median family income was $\$ 5,620$, while in 1976 the average family had $\$ 14,958$ to spend--nearly three times as much (Bureau of Census, 1977). There may be a commonly held view that a rise in income produces an equal rise in food expenditure, but this is not 
necessarily true. Food expenditure is relatively inelastic. In other words, while the total amount spent on food increases, the percentage of income allotted for food expenditure is relativeIy static and may even decline. This is shown in table 1 .

TABLE 1

FOOD EXPENDITURES AS A PROPORTION OF TOTAL AFIER-TAX INCOME (NATIONAL ESTIMATES)

\begin{tabular}{llcl}
\hline Year & $\begin{array}{l}\text { Prepared } \\
\text { at Home }\end{array}$ & $\begin{array}{c}\text { Consumed Away } \\
\text { from Home }\end{array}$ & Total \\
\hline 1960 & $16.1 \%$ & $4.1 \%$ & $20.2 \%$ \\
1961 & $15.8 \%$ & $4.2 \%$ & $20.0 \%$ \\
\hline 1972 & $12.5 \%$ & $3.8 \%$ & $16.3 \%$ \\
1973 & $12.5 \%$ & $3.8 \%$ & $16.3 \%$ \\
1974 & $13.1 \%$ & $3.9 \%$ & $17.0 \%$ \\
1.975 & $13.0 \%$ & $4.1 \%$ & $17.1 \%$ \\
1976 & $12.7 \%$ & $4.1 \%$ & $16.8 \%$ \\
\hline
\end{tabular}

Source: Economic Research Service, U.S. Dept. of Agriculture

It can be seen that the percentage of income spent on food in 1960 was 20.2 percent while in 1976 it was 16.8 percent--a decrease of 3.4 percent. (Census, 1977).

There are socio-economic variables that influence this trend. One of these is the decroase in consumer value of the dollar as was evidenced by the drop from 1.13 in 1960 to .59 in 1976-nearly 50 percent. Another factor is the increase in the cost of food. For the same period of time some food items rose in price nearly 42 percent (Census, 1977).

of significance to the present research study is the 
decrease in percentage of income spent on food prepared at home from 16.1 percent in 1960 to 12.7 percent in 1976; while the amount spent on food consumed away from home remained the same 4.1 percent from 1960 to 1976 after a slight .3 variance in 1972-74. Per capita weekly food expenditures for 1960-61 and 1972-74 are shown in table 2. (Rogers \& Green, 1978).

As might be expected, those fanilies in a higher income bracket showed a proportionate incrase in total food expenditure. In this study conducted by Rogers and Green, the significance of increase is evidenced within each yoar by the higher percentage of money spent on food away from home. It is interesting to note that food expenditure at home decreased by the exact percenta.ge it increased away from home.

Household size. The relationship between household size and per capita food expenditure is shown in table 3, where it will be noted that as family size increased food expenditures decreased for both 1960-61 and 1972-74. Percentage of food expenditure outside the home also decreased as family size incrsased.

\section{Place of residence. Persons in the northeastern United} States, according to Rogers and Green, showed the highest total per capita food expenditure, while those in the southern United States showed the lowest expenditure on food. Westernexs show the highest percentage of food expenditure outside the home, with the South again showing the lowest. Food expenditures, both at home and away from home, were shown to be lower in non-metro- 
TABLE 2

PER CAPITA WEEKLY FOOD EXPENDITURES PER INCONE LEVEL 1960-61, 1972-74

\begin{tabular}{|c|c|c|c|c|c|c|c|c|c|c|}
\hline \multirow[t]{2}{*}{ Income } & \multicolumn{4}{|c|}{$\begin{array}{r}1960-61 \\
\text { Away }\end{array}$} & \multirow{2}{*}{$\frac{\text { Total }}{\text { Dollars }}$} & At $\mathrm{H}$ & & \multicolumn{2}{|c|}{$1972-74$} & Total \\
\hline & Dollars & $\%$ & Dollars & $\%$ & & Dollars & $\%$ & Dollars & $\%$ & Dollars \\
\hline Under $\$ 3,000$ & 4.67 & 85 & .81 & 15 & 5.48 & 7.56 & 83 & 1.53 & 17 & 9.09 \\
\hline$\$ 3,000-4,999$ & 5.34 & 82 & 1.15 & 18 & 6.49 & 8.15 & 82 & 1.82 & 18 & 9.97 \\
\hline$\$ 5,000-9,999$ & 6.32 & 81 & 1.49 & 19 & 7.81 & 8.00 & 76 & 2.47 & 24 & 10.47 \\
\hline$\$ 10,000-14,999$ & 7.30 & 75 & 2.39 & 25 & 9.69 & 8.39 & 74 & 3.03 & 26 & 11.42 \\
\hline$\$ 15,000+$ & 8.89 & 69 & 3.98 & 31 & 12.87 & 9.26 & 67 & 4.60 & 33 & 13.86 \\
\hline A. verage & 6.50 & 78 & 1.96 & 22 & 8.47 & 8.27 & 76 & 2.69 & 24 & 10.96 \\
\hline
\end{tabular}


TABLE 3

PER CAPITA WEEKLY FCOD EXPENDITURES BY HOUSEHOLD SIZE $1960-61,1972-74$

\begin{tabular}{|c|c|c|c|c|c|c|c|c|c|c|}
\hline \multirow{2}{*}{$\begin{array}{l}\text { No. of } \\
\text { Persons } \\
\text { in Family }\end{array}$} & \multicolumn{5}{|c|}{$1960-61$} & \multicolumn{5}{|c|}{$1972-74$} \\
\hline & $\frac{\text { At Ho }}{\text { Dollars }}$ & $\%$ & Away & $\%$ & $\frac{\text { Total }}{\text { Dollars }}$ & $\frac{\text { At } H}{\text { Dollars }}$ & $\%$ & Awas & $\%$ & $\frac{\text { Total }}{\text { Dollars }}$ \\
\hline 1 & 7.25 & 62 & 4.45. & 38 & 11.70 & 9.37 & 60 & 6.18 & 40 & 15.55 \\
\hline 2 & 8.01 & 80 & 1.98 & 20 & 9.99 & 10.19 & 73 & 3.78 & 27 & 13.97 \\
\hline 3 & 6.73 & 80 & 1.73 & 20 & 8.46 & 8.69 & 73 & 3.19 & 27 & 11.88 \\
\hline 4 & 6.03 & 82 & 1.36 & 18 & 7.39 & 7.94 & 74 & 2.75 & 26 & 10.69 \\
\hline $5+$ & 4.78 & 84 & .91 & 16 & 5.69 & 6.83 & 78 & 1.97 & 22 & 8.80 \\
\hline
\end{tabular}


politan areas as opposed to metropolitan areas. This is possibly due to increased production of farm products in non-metropolitan. areas and difference in life style and income levels.

Age of family head. Total per capita food expenditure was highest for those in the age bracket of $55-64$ in both time periods, namely; 1960-61, 1972-74. According to Rogers and Green there was a significant increase in food expenditure outside the home for all age groups in 1972-74 over 1960-61-with those under 25 showing greatest increase and those over 64 the least. (See table 4.)

Peaks in per capita expenditures for food away from home were evident when the household head is under 25 years of age and when yearly family income exceeds $\$ 15,000$.

This could be good news for the restaurant industry since the major portion of the restaurant market today is made up of households headed by 25-34 year olds. The Bureau of Census (1977) estjmates this segment of the population will continue to expand at the rate of 656,000 households per year through 1980 . The increase in younger household heads may be significant for natural food restaurants as the younger segment of population have shown a keen interest in a more simple diet.

Trends in Health and Nutrition Historically, prosperity and security have engendered a rich diet of animal foods and wine, but the pendulum swings back and forth and often periods of gross excesses engender an increase 
TABLE 4

PER CAPITA WEEKLY FOOD EXPFNDITURES BY AGE OF HOUSEHOLD HEAD 1960-61., 1972-74

\begin{tabular}{|c|c|c|c|c|c|c|c|c|c|c|}
\hline \multirow{3}{*}{ Age } & \multicolumn{5}{|c|}{$1960-61$} & \multicolumn{5}{|c|}{$1972-74$} \\
\hline & At $\mathrm{H}$ & & Awaj & & Total & At $\mathrm{HC}$ & & Awa & & TotaI \\
\hline & Dollars & $\%$ & Dollars & $\%$ & Dollars & Dollars & $\%$ & Dollaxs & $\%$ & Dollars \\
\hline Under 25 & 4.87 & 74 & 1.72 & 26 & 6.59 & 6.57 & 64 & 3.71 & 36 & 10.28 \\
\hline $25-34$ & 5.19 & 79 & 1.36 & 21 & 6.55 & 7.11 & 70 & 3.04 & 30 & 10.15 \\
\hline $35-44$ & 5.80 & 80 & 1.46 & 20 & 7.26 & 7.61 & 73 & 2.75 & 27 & 10.36 \\
\hline $45-54$ & 6.61 & 80 & 1.69 & 20 & 8.30 & 8.88 & 73 & 3.36 & 27 & 12.24 \\
\hline $55-64$ & 7.41 & 79 & 1.97 & 21 & 9.38 & 9.70 & 75 & 3.25 & 25 & 12.95 \\
\hline $64+$ & 7.03 & 85 & 1.26 & 15 & 8.29 & 9.88 & 81 & 2.37 & 19 & 12.25 \\
\hline
\end{tabular}


in advocacy for simplicity (Seejig, 1976). Today the pendulum seems to be going towards a more naturalistic approach to diet. The movement begun a few years ago by the youth is moving up through the ranks as these youth grow up and establish homes of their own. Young adults tend to be more educated and appear to have stronger values of simplicity and personalization than their predecessors. They read labels and are more interested in the nutritional value of meals purchased away from home, as well as those eaten at home, and are willing to pay a premium for what they consider to be "healthy foods" (primarily fruits and vegtables) (Soller, 1976).

A recent study of 132 couples in two midwestern cities bears out this trend. Of the twelve reasons given for making decisions about food selection, health and nutrition ranked first and fourth as will be seen in table 5 (Shafer, 1978).

\section{Trends in the Restaurant Industry}

Natural foods. The restaurant industry has moved quickly to capture a corner of the ratural foods market and realize a share of the profits. There has been an increase in the number of restaurants offering strictly "natural foods." The more simple menu is often served in a natural setting of potted plants and wood planked foors. These are known as concept restaurants where decor, menu, table setting, and service support a single theme. Researchers predict that this type of restaurant has a good chance of survival in the changing narket place (Eagen \& Cingolani, 1977).

Another form that the natural foods trend is taking in 
TABLE 5

RANKIING OF REASONS FOR MAKING

DECISIONS ABOUT FOOD

\begin{tabular}{|c|c|c|c|c|c|}
\hline \multicolumn{3}{|c|}{ HUSBANDS } & \multicolumn{3}{|c|}{ WIVES } \\
\hline Reasons & $\begin{array}{l}\text { Rank } \\
\text { Score }\end{array}$ & Rank & Reasons & $\begin{array}{l}\text { Rank } \\
\text { Score }\end{array}$ & Rank \\
\hline Taste & 294 & 1 & Nutrition & 281 & 1 \\
\hline Nutrition & 199 & 2 & Taste & 261 & 2 \\
\hline Cost & 147 & 3 & Cost & 196 & 3 \\
\hline Health & 127 & 4 & Health & 126 & 4 \\
\hline Appearance & 100 & 5 & Convenience & 69 & 5 \\
\hline Converience & 94 & 6 & Habit & 67 & 6 \\
\hline Habit & 64 & 7 & Weight contol & 61 & 7 \\
\hline Appropriate & 39 & 8 & Appeárance & 53 & 8 \\
\hline $\begin{array}{l}\text { Weight } \\
\text { control }\end{array}$ & 35 & 9 & Appropriate & 41 & 9 \\
\hline odor & 27 & 10 & Texture & 7 & 10 \\
\hline Texture & 14 & 11 & Novelty & 4 & 11 \\
\hline Novelty & 10 & 12 & Odor & 2 & 12 \\
\hline
\end{tabular}


the restaurant industry is the blending of. "what people are accustomed to eating and what's good for them." A little restaurant in New York called Fruity's is an example of this. In addition to salmon steaks, filet of sol, and fish kebobs, there are omelets and eggplant parmigiana. Carrot and banana cakes share the menu with goats milk yogurt, and health shakes, herbal teas, and mineral waters vie with coffee and alcoholic beverages to round out the $\$ 20,000$ a week sales volume ("Health Food Restaurant", 1976).

Even the "big guns" of the fast food chains are adapting their menus to the "natural" trend. For example, hamburger and. pizza houses have added salads, and the Marriott Corporation, in their Great American Theme Parks, have added the popular Bugs Bunny fresh fruit and vegetable bins (Soller, 1976).

There is evidence that exclusive dining places have been affected by America's changing eating patterns, as well. The Leopard, eastside New York's plush restaurant, is offering dishes made from organic ingredients. This means that organic foods which have had a decidedly plebian image have moved up in the ranks in an astonishing way. The real significance of this startling departure from the traditions of haute cuisine, according to Weiss (1971) is that it reflects the new standards of its changing customer. . . the young generation which is firmly committed to health foods.

Sales volune increase. The food service industry can be proud of its annual sales record. Forty-four billion doliars is not "chicken feed." Since 1968 sales volume has increased at 
a rate of approximately $12-13$ percent a year. And each year groater numbers of ating establishments gross in excess of one million dollars. Of the states, California leads the Pacific coast and the nation in retail sales for eating and drinking establishments. It grosses 4.5 billion dollars annually from its 36,913 eating places (one for every $483^{\circ}$ residents). Washington state is second among Pacific coast states with 674 million dollars in sales per year. The ranking of Pacific coast states is shown on table 6 (Rogers \& Green, 1978).

TABLE 6

PACIFIC COAST RETAIL TRADE

EATING AND DRINKING ESTABLISHMENTS

1977

\begin{tabular}{lrr}
\hline State & No. & Sales Vol. \\
\hline Califormia & 36,913 & $\$ 4,588$ billion \\
Washington & 6,063 & $\$ 674$ million \\
Oregon & 4,298 & $\$ 439$ million \\
Hawaii & 1,418 & $\$ 261$ million \\
Alaska & 662 & $\$ 87$ million \\
Total Pacific Coast & 49,354 & $\$ 6,049$ bilion \\
\hline
\end{tabular}

Food service is big business. Last year 3.5 million Ainericans oarned their livlihood in the business and the United States Bureau of Labor predicts by 1985 another 875,000 will have joined the ranks. Trade publications project the industry will 
have become the nation's number one employer by 1988 absorbing a quarter of a million new workers annually (Eagen \& Cingolani, 1977). While the restaurant industry is big business, it appears to be a very complex and risky business even in times of stable national economy.

Risk potential. According to Kroc (1977), founder of the successful. McDonalds Corporation,

Restauranting is a risk, but you must take that risk if you want to succeed. In some cases you must go for broke. If you believe in something, you've got to be in it to the ends of your toes. You must be willing to take the risk involved in our free-enterprise system. It is the only way in the world to economic freedom. (p. 192)

It appears that survival is exactly what it's about in the food service industry as a whole. In spite of its collective success there are many uncertainties. Fluctuating food costs, energy shortages, and personnel problems are but a few of the challenges facing today's manager. Findings infer it requires a high degree of skill and training to operate a food service facility in a financially sound manner. Veteran operators warn that no other type of business is as denanding of time or requires more attention to a multiplicity of details (Eagen \& Cingolani, 1977).

Each year fortunes are lost and enthusiasms shattered by bankrupt food establishments. Dun and Bradstreet reported that 779 eating places closed their doors in 1976 leaving debts or nearly \$100 million dollars. This does not include the restaurants that closed down without owing debts (Eagen \& Cingolani, 1977).

Vegetarian or nautral food restaurants shared in this 
failure rate. According to a nation-wide survey conducted by this researcher, out of a total of 236 questionnaires sent out 75 were returned with notations of "no longer at this address" or "no forwarding address," which indicates that these restaurants were no longer in business. Of the 68 completed questionnaires received, most owners/managers indicated they had had no previous food service experience or training.

This review of literature has revealed factors and trends related to American food expenditures, interest in health and nutrition by younger adults, and a reflection of these trends as shown in the restaurant industries sales volune, and adaptation of service.

The research design described in chapter III was developed to provide a data base from which to compare the relationship of local and national trends in an attempt to determine the feasibility of developing a natural foods restaurant in the TriCity, Washington area. 
CHAPTER III

\section{METHODS}

This research design was developed to determine the feasibility of establishing a natural foods restaurant in TriCities, Washington. Based on findings in the review of literature, this study will incorporate the survey rnethod of discovering the eating-out habits of area residents as it relates to the significant factors of age, income, and family size. Particular effort will be made to discover the interest in and patronization of natural foods restaurants. This chapter will give emphasis to (1) locale, (2) sample selection, (3) data collection, and (4) data ireatment.

\section{Locale}

Geographical. Pasco, Richland, and Kennewick, three adjacent cities in southeastern Washington, comprise what is known as the Tri-Cities metropolitan area. Located 380 feet above sea level at the confluence of the Snake, Columbia, and Yakima Rivers, the cities offer every opportunity for developing a successful business (SBA, 1973).

Population. The population of the three cities is not a homogenous conglomerate. Pasco, known as the port city, has the earliest origins and the most stable population. Richland, 
the last of the three to be incorporated, serves as a bedroom community for the noarby Hanford Nuclear scientists, engineers, and support personnel. Kennewick, located between Pasco and Richland along the south shores of the Columbia, is fast becoming the commercial center for the Tri-Cities. (See figure 1.)

The 1978 population total for the three cities is 75,331; an increase of 18,802 over 1970 (Tri-Cities Chamber of Commerce, 1978).

TABLE 7

POPULATION STATISTICS FOR THE TRI-CITIES

\begin{tabular}{lcccc}
\hline City & 1970 & 1976 & 1977 & 1978 \\
\hline Kennewick & 15,212 & 21,301 & 23,483 & 26,669 \\
Pasco & 13,920 & 14,618 & 15,499 & 15,588 \\
Richland & 27,397 & 13,570 & $\underline{33,067}$ & 33,074 \\
& 56,529 & 67,489 & 72,049 & 75,331 \\
\hline
\end{tabular}

Resources. Important resources offered by the area are: (1) abundant water supply with low energy rates, (2) diversified agriculture and industry, (3) highly skilled, highly stable labor force with less than 5 percent unemployment rate, (4) mild climate, (5) space for expansion, (6) crossroads location for transportation by air, rail, water, and highway, and (7) a sound financial base showing steady economic growth.

Often referred to as the place to enjoy "desert sun and 


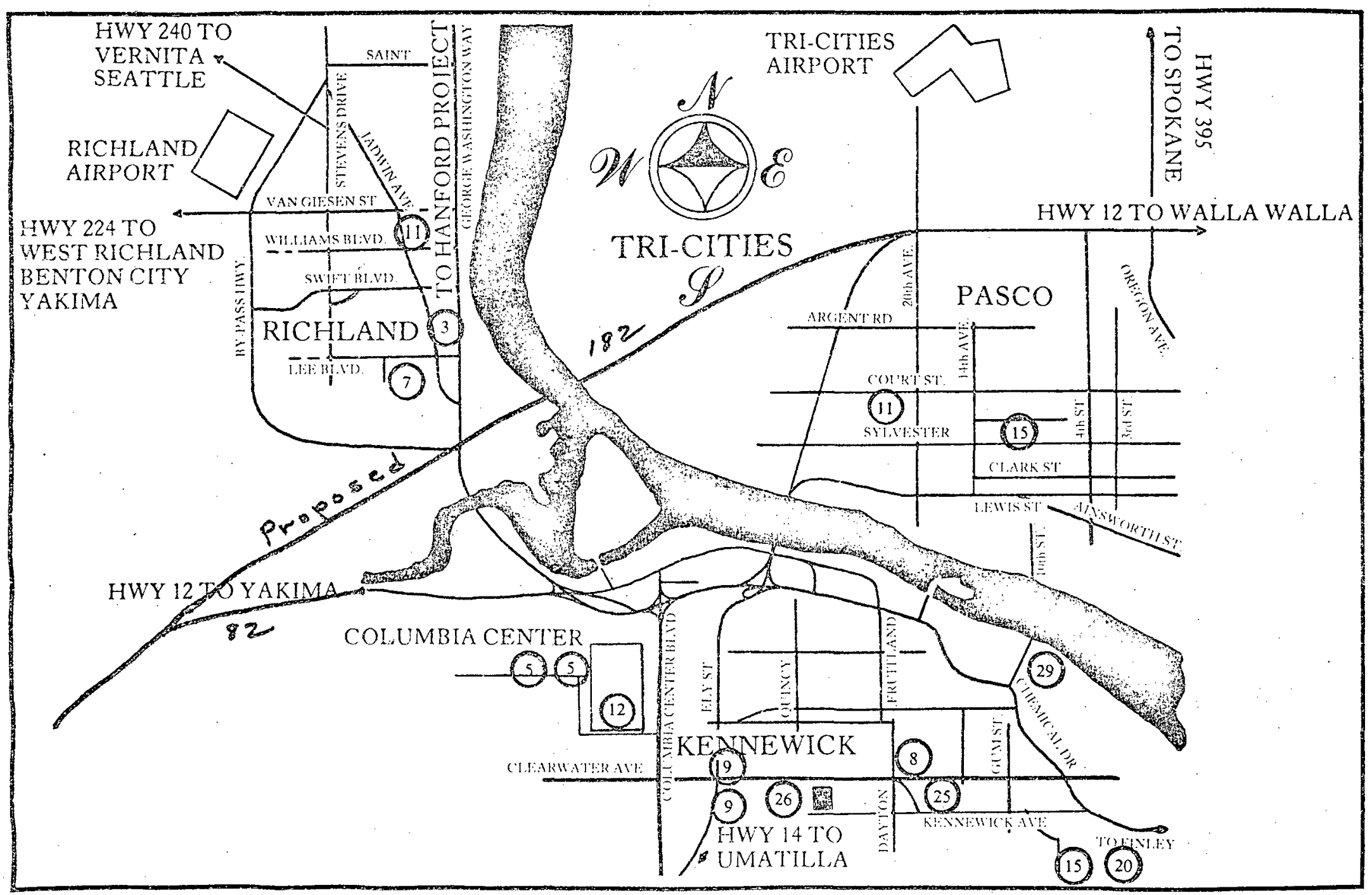

Figure 1. Tri-Cities, Washington 1978 
water fun," the Trj-Cities, with its average mean annual temperature of 53.6 and approximately 300 days of sunshine per year, has become a.key convention center for the state and the nation (Tri-Cities Chamber of Commerce, 1978).

Financial base. Income figures for the Tri-City area indicate that the average yearly family income is $\$ 16,100$ making it the fourth highest in the state with the lowest 10 percent earning under $\$ 5,542$ and the highest 10 percent over $\$ 36,710$. Further, income for Tri-Citians is increasing at the second fastest rate of the nation's 260 major metropolitan areas--exceeded only by Alaska (Tri-City Herald, April 9, 1978). This rate of increase is reflected in the retail spending pattern of the Tri-Cities.

Table 8 shows a 77.5 million dollar increase in 1977 expenditures over 1976 (T'ri-Cities Chamber of Commerce, 1978).

TABLE 8

TRI-CITY RETAII SALES

\begin{tabular}{lcc}
\hline City & 1976 & 1977 \\
\hline Kennewick & $201,469,100$ & $249,018,644$ \\
Pasco & $184,577,196$ & $158,911,438$ \\
Richland & $131,602,594$ & $187,305,249$ \\
Totals & $517,648,890$ & $595,235,331$ \\
\hline
\end{tabular}


Shopper mobjility. A survey conducted by this researcher to discover the mobility of Tri-City shoppers at three major shopping centers in the area, on three consecutive days, revealed that migration was not significant between cities. However, the Cclumbia Shopping Center located half-way between Kennewick and Richland attracted the highest number of shoppers and highest jercentage from out-of-town. (See table 9.)

TABLE 9

TRI-CITY SHOPPER MÒBILITY

\begin{tabular}{|c|c|c|c|c|c|c|}
\hline \multirow{2}{*}{$\begin{array}{l}\text { Shoppers } \\
\text { From: } \\
\text { Richland }\end{array}$} & \multicolumn{2}{|c|}{$\begin{array}{l}\text { July } 1.1 \\
\text { Highland Ctr. } \\
\text { Kennewick }\end{array}$} & \multicolumn{2}{|c|}{$\begin{array}{c}\text { July } 12 \\
\text { Court St. Plaza } \\
\text { Pasco }\end{array}$} & $\begin{array}{l}\text { July } \\
\text { Col. }\end{array}$ & \multirow{2}{*}{$\begin{array}{l}\begin{array}{l}13 \\
\text { Ctr. }\end{array} \\
20 \%\end{array}$} \\
\hline & 17 & $.11 \%$ & 2 & $2 \%$ & 45 & \\
\hline Kennewick & 52 & $76 \%$ & 9 & $11 \%$ & 91. & $40 \%$ \\
\hline Pasco & 3 & $4 \%$ & 61 & $75 \%$ & 30 & $13 \%$ \\
\hline Out-of-town & 6 & $9 \%$ & 9 & $11 \%$ & 62 & $27 \%$ \\
\hline $\begin{array}{l}\text { No. Inter- } \\
\text { viewed }\end{array}$ & 78 & $100 \%$ & 81 & $100 \%$ & 228 & $100 \%$ \\
\hline
\end{tabular}

Competition. One phase of this research was directed toward a study of the competition in the area. A review of the yellow-page directory revealed the names and addresses of approximately 140 eating places in the following distributions: Pasco 56, Kennewick 46, Richland 38. (See appendix.)

It was further discovered, through contacts with the planning director for each city, that approximately six new 
eating places were planned for the Tri-Cities before the end of the year. This brought the total number of restaurants in the Tri-City area to 146. Arranged according to category of service the distribution looks like this:

\begin{tabular}{lc} 
Type of Service & Number \\
\hline Fast Foods & 68 \\
Family Dining & 33 \\
Fine Dining & 9 \\
Truck Stops \& Cafes & 15 \\
Taverns & 20 \\
Night Clubs & 1 \\
Total & 146
\end{tabular}

Applying the national population average per ating establishment (575), it appears that the Tri-Cities is pretty well supplied with restaurants. Any decision for developing further restaurant service would need to give prime consideration to the type of service most needed.

Sample Selection

A random sample of Tri-City residents was selected in the following inanner: (1) commercial numbers were crossed out of the white pages of the telephone directory; (2) the pages were removed from the directory and each column of numbers was cut away from the names; (3) the strips of telephone numbers were placed in a pile and sufficiently mixed to permit even distribution; (4) 100 stxips, approximately 6,000 numbers, were drawn from this pile; 
(5) four strips were taped to a page; (6) the pages were then photo copied to prevent observation of the alphabetical listing on the back side of the pages and possible identification of the respondents.

Telephones with prefix 582, 586, and 783 for Kennewick were designated as Code 1; prefix 545 and. 547 for Pasco as Code 2; and prefix 942, 943,945, 946, 947, 948, and 967 for Richland as Code 3。 (see appendix.)

\section{Data Collection}

Method. The descriptive survey method was used for purposes of this study--where the researcher described what she had uncovered through minimal probing by means of an interviewing process with a structured questionnaire.

Questionnaire. One of the initial steps in this research was to develop tools for use in data collection that would provide the necessary information. In order to do this the major problem was divided into sub problems in the following manner:

Major Problem: To determine the feasibility of developjng a natural foods restaurant in Tri-Cities, Washington.

Sub Problems: To study eating-out patterns of a random sample of area residents for (1) actual behavior, (2) predicted behavior, (3) preferences, and (4) interest as it relates to demographic characteristics and natural foods restaurants.

The researcher then determined the questions appropriate for the major and sub problems listed above in order to assess 
the interest and attitudes of the community towards a natural foods restaurant. A questionnaire was structured--with a lead--in question to create interest and build confidence and provide psychological sequencing of subsequent questions from simple to complex. The. questions were designed primarily to quiz the respondent on his actual eating-out behavior as it was felt this would more likely elicit accurate responses. Questions relating to natural foods and natural foods restaurants were left until later in the questioning process, as were requests for demographic information, in order to allow time to build confidence and to avoid prejudice as much as possible. (See appendix for sample questionnaire.)

Questions were then categorized according to the following arrangement:

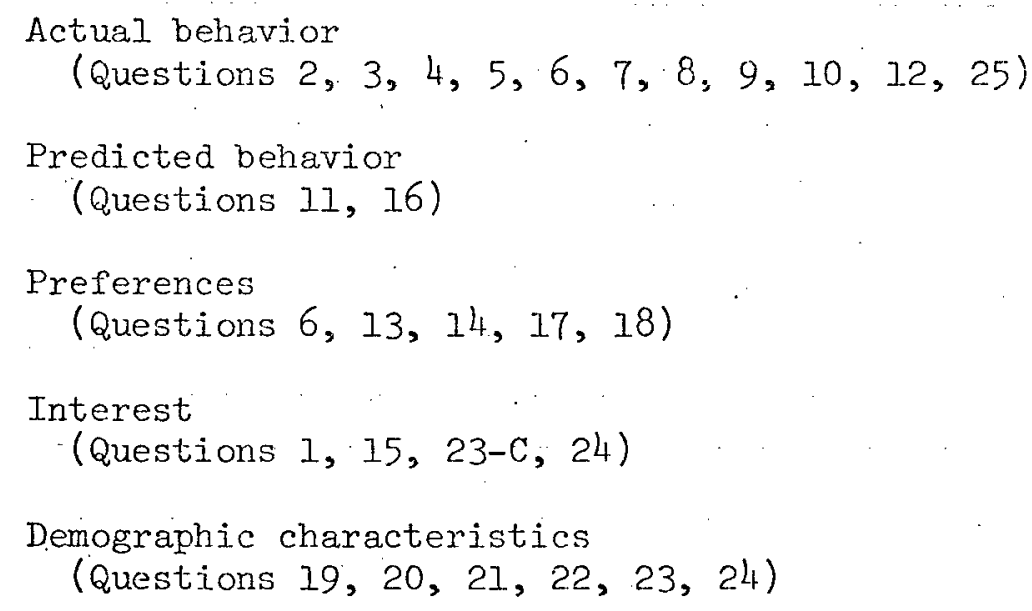

Question number 15 asked the interviewees "what in their opinion was the type of eating place most needed in the Tri-Cities." This was placed in the questionnaire before any mention of natural foods to avoid bias of the respondents' suggestions.

A pretest of the original questionnaire was administered to select individuals, and their evaluation and appropriate 
suggestions for clarity and content were incorporated--such as more specific requests for information relating to a natural foods restaurant.

Survey method. The structured questionnaire was specially designed for use in a telephone survey. This method for securing research data was chosen because preliminary study revealed that individuals are more likely to respond to a telephone survey than to a questionnaire survey. It is also a fast method of collecting data and is economical to administer. Possible problems inherent in the telephone survey are: (1) the difficulty of determining the most convenient time for the interviewee, and (2) many people do not wish to respond to questions from someone they do not know. Thus it is apparent that good rapport with the person being called must be established as early in the questioning process as possible. (Note the method of selecting telephone numbers on page 25.)

Twenty-three interviewers were selected to make the telephone contacts. A list of sixty names was secured from the secretary of a large church in the Tri-City area. Most of these individuals had previously assisted with telephone surveys and they were usually willing to participate in such volunteer activity. The resoarcher contacted the potential interviewers by telephone and found twenty-three who were willing to serve. The researcher then went to the home of oach interviewer and gave him/her personal instructions as to the procedures of conducting the survey. A printed procedures sheet was provided 
along with a typewritten message to be used in the interview. Close adherence to this instruction was urged to standardize the interviewing process as much as possible. (See appendix.)

The interviewer was to read the questions exactly as they appeared on the questionnaire and to enter data as they went through the interviewing process. After each call was completed, they were to immediately go back over the questionnaire to clarify any ambiguities and fill in any additional information.

Each interviewer was asked to conduct 25 interviews with the ultimate goal of 575 completed questionnaires. This number was selected because it represents the national average of population per restaurant (Los Angeles Times, October 24, 1971).

Time alotted for data gathering was limited to approximately ten days--November 10-20, 1978. The calls were not confined to any particular time of day but were made at various times throughout the ten day period--at the convenience of the interviewer.

The actual number of completed interviews was 439 , thirty-three of which were discarded because they were for calls outside of the immediate Tri-City area. This left a remaining 406 questionnaires to tabulate and analyze (or 70 percent of the original goal).

\section{Data Treatment}

The completed questionnaires were collected by the resoarcher, reviewed for clarity, and separated according to city. The researcher then worked with a programmer from Andrews 
University Computing Center to develop a set of instructions for tallying and cross tabulating the data in the most meaningful manner. At this point, it was found necessary to code each question numerically for ease of entry onto the computer. The terminal method was chosen for processing the information rather than key punching in order to save time, and the data processing staff entered the data.

A statistics analyst reviewed the results of the processed data for accuracy and reliability and gave suggestions for securing more specific information from the computer. One of the suggestions was to limit the number of variables per questions to responses most important to the study. This technique would provide a greater spread between responses and in turn show a greater degree of variance. These recommendations were followed and the additional information was secured. A set of tables was then drawn up, one table for each question, and the data were entered therein.

Chapter IV describes the data analysis and suggests possible application of the findings. 
CHAPTER IV

FINDINGS AND DISCUSSION

The discussion of the survey findings of this study are given in chapter IV. A step by step analysis of questionnaire responses is presented.

\section{Findings}

Tri-City area where the study was conducted is reflected in the number of responses for ach of the cities. Distribution of the total sample, consisting of 406 interviews, is shown in table 10. Kennewick made up the largest segment with 175 responses or 43 percent of the interviews, and Pasco and Richland shared equally the remaining 56 percent of the total sample.

TABLE 10

TRI-CITY TOTAI SAMPLE

\begin{tabular}{lcc}
\hline City & $\mathrm{N}$ & $\%$ \\
\hline Kennewick & 175 & 43.10 \\
Pasco & 116 & 28.57 \\
Richland & 115 & 28.33 \\
Total & -107 & 100.00 \\
\hline
\end{tabular}


In response to question one, "Do you enjoy eating out?" the majority of persons surveyed (374 out of 406) said they did indeed enjoy eating out. Only one respondent said they could not. afford to eat out and 17 said they did not enjoy it. In question two respondents were asked, "How of ten do you eat out?" One hundred fifty-eight persons (39 percent) said they ate out at least once a week, while 79 ( 19 percent) said they ate out more than once a week. The interesting factor in table II is that over half of the persons responding ( 58 percent) said they ate out at least once a week.

TABLE 11

FREQUENCY OF EATING OUT

\begin{tabular}{lcc}
\hline Frequency & N & $\%$ \\
\hline No response & 4 & .99 \\
Once/Wk. & 158 & 38.92 \\
Once/Mo. & 72 & 17.73 \\
More/1/Wk. & 79 & 19.46 \\
More/I/Mo. & 59 & 14.53 \\
Less/I/Mo. & 34 & 8.37 \\
Totals & -106 & 100.00 \\
\hline
\end{tabular}

In table 12 it will be seen that 301 ( 74 percent) of the sample said they had eaten out within seven days of the survey date, and 45 (11 percent) said they had eaten out within two weeks of the survey date. This means that at least 74 percent 
of all respondents indicated they had eaten out within two weeks of the survey date.

TAB BLE 12

EATING-OUT HISTORY

\begin{tabular}{lcc}
\hline Frequency & N & $\%$ \\
\hline No Response & 19 & 4.68 \\
$1-4$ Days & $301\left\{\begin{array}{ll}197 & 48.52 \\
104 & 25.62\end{array}\right\} 74 \%$ \\
$5-7$ Days & 45 & 11.08 \\
Over 2 Weeks & 41 & 10.10 \\
Totals Days & 406 & 100.00 \\
\hline
\end{tabular}

Question four asked the interviewees what occasion prompted them to eat out? Three hundred twenty-five or 82 percent of those responding said there was no particular occasion involved.

When asked in question five how many persons were in their party, 146 (36 percent) of the respondents said two, while 87 (21 percent) said four persons made up their party, and 54 (13 percent) gave three persons as the size of their party. Except for a few large groups of fifteen or more persons, the first three categories made up 77 percent of the total sample. A calculation of the number of responses times number of persons in party revealed 1420 persons had dined out within a month of the survey date. 
TABLE 13

TYPES OF EATING PLACES PATRONIZED

\begin{tabular}{lcc}
\hline Type & N & $\%$ \\
\hline Dining Lounge & 170 & 41.87 \\
Fast Food & 97 & 23.89 \\
Family Served & 95 & 23.40 \\
Cafeteria & 24 & 5.91 \\
Specialíy & 10 & 2.46 \\
No Response & 6 & 1.48 \\
Other & 4 & .99 \\
Totals & 4.06 & 100.00 \\
\hline
\end{tabular}

Tabie 13 reveals the response to question six. As can be seen of respondents, 170 ( 42 percent) chose to eat in a restaurant with lounge, while the fast food and family restaurants showed similar patronage, 97 (24 percent) and 95 (23 percent), respectively. Cafeterias, specialty houses, and four miscellaneous type eating places claimed only 11 percent of the business.

Question seven asked the respondent to approximate the cost of the meal for the entire group. The total dollars reported for all persons responding added up to $\$ 6,062$. This sum divided by 1,420 (number of persons reported in question five) showed the approximate cost per meal as $\$ 4.27$ per person excluding tips and liquor. 
The respondents were quizzed in question eight as to whether they had eaten previously at the restaurant referred to in question six. Three hundred twenty-nine (approximately 81 percent) stated they had, while 68 (17 percent) indicated they had not.

Interviewees indicated in response to question nine that 154 (38 percent) of them had traveled five miles or more to eat out, as shown in table 14. Two hundred forty-nine (62 percent) said they traveled less than five miles.

\section{TABLE 14}

DISTANCE TRAVELED TO EAT OUT

\begin{tabular}{lcc}
\hline Distance & N & $\%$ \\
\hline No Response & 3 & .74 \\
Less than Mile & 54 & 13.30 \\
1 Mile & 61 & 15.02 \\
2 Miles & 60 & 14.78 \\
3 Miles & 43 & 10.59 \\
4 Miles & 31 & 7.64 \\
5-10 Miles & 119 & 29.31 \\
Over 10 Miles & 35 & 8.62 \\
Totals & 406 & 100.00 \\
\hline
\end{tabular}

Most persons, 318 or 78 percent, responding to question ten indicated that they had traveled to a location with the 
specific intent to eat out.

Question eleven asked how far the interviewees would be willing to travel in order to eat out.: The responses revealed 56 percent would travel over ten miles, while 40 percent said they would not travel more than nine miles.

Question number twelve was designed to find if the respondents tried any new foods. This was an attempt to discover the respondents' attitude toward new concepts in foods. Sixteen percent of the persons queried indicated they had tried a new food item, while 84 percent said they had not tried new food items.

Table 15 illustrates the importance of quality as viewed by the customer. Of the 385 persons responding to question thirteen, which asked for the most important feature in restaurant food service, 257 ( 64 percent) voted for quality, 81 (20 percent) for service, and 32 ( 8 percent) for atmosphere.

\section{TABLE .15}

IMPORTANT FEATURES OF RESTAURANT FOOD SERVICE

\begin{tabular}{lrr}
\hline Foature & N & \multicolumn{1}{c}{$\%$} \\
\hline Quality of Food & 256.6 & 63.75 \\
Service & 81.6 & 20.08 \\
Atmosphere & 31.6 & 7.80 \\
No Response & 21.0 & 5.17 \\
Price & 10.2 & 1.97 \\
Quantity of Food & 5.0 & 1.23 \\
Location & -- & ---1 \\
Other & -- & -100.00 \\
Totals & 406.0 & 100 \\
\hline
\end{tabular}


American held first place ( 34 pereent of votes) when the respondents were given a choice of favorite ethnic foods in question 14. (See table 16.) Chinese ranked second with 28 percent, Mexican third with 20 percent, and Italian came in fourth at 14 percent.

TABLE 16

FAVORITE ETHNIC FOODS

\begin{tabular}{lcc}
\hline Food & N & $\%$ \\
\hline American & 138.75 & 34.17 \\
Chinese & 112.75 & 27.77 \\
Mexican & 79.75 & 19.64 \\
Italian & 56.75 & 13.97 \\
Other & 7.0 & 1.73 \\
No Response & 6.0 & 1.48 \\
German & 4.0 & .99 \\
Polynesian & 1.0 & .25 \\
Totals & 406.00 & 100.00 \\
\hline
\end{tabular}

Interviewees were asked what type of restaurant they felt was most needed in the Tri-Cities. Fifty-one persons (13 percent) of those interviewed felt there were enough restaurants in the area already. One hundred three (25 percent) did not respond. The remaining 62 percent was divided among 21 percent who favored specialty restaurants, 17 percent who wanted more fine dining facjlities, and 13 percent who suggested that more family type 
restaurants were needed. It was interesting to note that 4.4 percent of the respondents were desirous of having a natural foods restaurant to patronize. Suggestions from which to choose were not offered by the interviewer. See rankings of eating places perceived as most needed in table 17.

\section{TABLE 17}

TYPES OF EATING PLACES NEEDED IN TRI-CITLES

\begin{tabular}{lcc}
\hline Type & $\mathrm{N}$ & \multicolumn{1}{c}{$\%$} \\
\hline No Response & 103.0 & 25.37 \\
Specialty & 86.0 & 21.18 \\
Fine Jining & 72.0 & 17.73 \\
Family & 53.0 & 13.05 \\
None Needed & 51.0 & 12.58 \\
Natural Foods & 18.0 & 4.43 \\
Moderate Cost & 15.0 & 3.69 \\
Home Cooking & 8.0 & 1.97 \\
Totals & 406.0 & 100.00 \\
\hline
\end{tabular}

Most of the responses to part "A" of question sixteen, which asked whether the interviewee would patronize a natural foods restaurant, 74 percent gave a definite yes. Sixty-nine people (17 percent) of the sample stated no. There were few in-between answers as can be seen in table 18. 
TABLE 18

PREDICTED PATRONAGE OF

A NATURAL FOODS RESTAURANT

\begin{tabular}{lrc}
\hline Response & $\mathrm{N}$ & $\%$ \\
\hline Yes & 300 & 73.89 \\
No & 69 & 17.00 \\
Maybe & 15 & 3.69 \\
No. Response & 11 & 2.71 \\
Don't Know & 5 & 1.23 \\
Probably & 3 & .74 \\
Other & 3 & .75 \\
Totals & 406 & 100.00 \\
\hline
\end{tabular}

Interviewees were instructed in question seventeen to rank specific foods commonly served in natural foods restaurants (see table 19) as to their first, second, and third choice of preference if they were dining out.

Fresh fruit salads ranked first, taking 308 of the total vote, while homemade soup took second place with 168 perșons registering approval. Fresh vegetable salads placed third (151) and fourth highest was fresh baked bxead (144). Frozen yogurt desserts, vegetarian entrees, vegetarian sandwiches, and crepes shared the lowest acceptance vote.

Question eighteen was designed to discover whether the interviewees would prefer (1) a restaurant that served exclusively 
TABLE 19

FAVORITE NATURAL FOODS

\begin{tabular}{|c|c|c|c|c|c|c|c|}
\hline Food Item & $\begin{array}{c}\text { Overall } \\
\text { Tally }\end{array}$ & Ist & $\begin{array}{c}\text { Choice } \\
\%\end{array}$ & $\begin{array}{l}\text { 2nd } \\
\mathbb{N}\end{array}$ & $\begin{array}{c}\text { Choice } \\
\%\end{array}$ & $\frac{3 r d}{N}$ & $\begin{array}{c}\text { Choice } \\
\%\end{array}$ \\
\hline Fresh Fruit Salads & 308 & 127 & 31.28 & 48 & 11.82 & 38 & 9.36 \\
\hline Homemade Soup & 168 & 55 & 13.55 & 67 & 16.50 & 46 & 11.33 \\
\hline Fresh Vegetable Salads & 151 & 53 & 13.05 & 68 & 16.75 & 30 & 7.39 \\
\hline Fresh Baked Bread & 144 & 29 & 7.14 & 52 & 12.81 & 63 & 15.52 \\
\hline No Response & & 95 & 23.40 & 119 & 29.31 & 153 & 37.68 \\
\hline Quick Cooked Vegetables & 62 & 19 & 4.68 & 23 & 5.67 & 20 & 4.93 \\
\hline Vegetarian Entrees & 34 & 9 & 2.22 & 7 & 1.72 & 18 & 4.43 \\
\hline Crepes & 30 & 7 & 1.72 & 11 & 2.71 & 12 & 2.96 \\
\hline Vegetarian Sandwiches & 25 & 4 & .99 & 6 & 1.48 & 15 & 3.69 \\
\hline Frozen Yogurt Desserts & 24 & 8 & 1.97 & 5 & 1.23 & 11 & 2.71 \\
\hline Totals & & 406 & 100.00 & 406 & 100.00 & 406 & 100.00 \\
\hline
\end{tabular}


natural foods or (2) a restaurant that included a limited selection of natural foods along with regular fare. Most respondents (56 percert) said they would prefer regular fare (choice two) and 33 percent said exclusively natural foods (choice one). Eleven percent did not respond.

The replies to question nineteen showed the largest portion of household heads fell within the $25-34$ year old range (43 percent)。The smallest age groupings were found between 55 and 64 years and under 25 years. The remaining categories were relatively evenly distributed as will be seen in table 20 .

TABLE 20

AGE OF FAMTLY HEAD

\begin{tabular}{lcc}
\hline Age & $N$ & $\%$ \\
\hline No Response & 45 & 3.1 .08 \\
Under 25 & 16 & 3.94 \\
$25-34$ & 92 & 22.66 \\
$35-44$ & 83 & 20.44 \\
$45-54$ & 66 & 16.26 \\
$55-64$ & 39 & 9.61 \\
$64+$ & 65 & 16.01 \\
Totals & 406 & 100.00 \\
\hline
\end{tabular}

There was a high vote of non-response ( 47 percent) to the request for information on average yearly family income, but 
of those willing to report 128 individuals ( 32 percent) said their family income was $\$ 20,000$ or above. The remaining categories revealed rather small percentage as shown in table 21 in response to question twenty.

TABLE 21

AVERAGE YEARLY FAMILY INCOME

\begin{tabular}{lcc}
\hline Income & $\mathrm{N}$ & $\%$ \\
\hline No Response & 189 & 46.55 \\
Under 3000 & $-\ldots .22$ \\
$3000-4999$ & 9 & 2.27 \\
$5000-9999$ & 16 & 3.94 \\
$10,000-14,999$ & 27 & 6.65 \\
$15,000-19,999$ & 37 & 9.11 \\
$20,000+$ & 128 & 31.53 \\
Totals & 406 & 100.00 \\
\hline
\end{tabular}

It will be seen in table 22 that the largest segment of households ( 37 percent) reported in question 21 that the family head had attended college. The second largest number (32 percent) repcrted high school as the highest level of education for the family hoad.

The two-member family was most often reported (27 percent) in question twenty-two of this survey, while second in size was the family of four (19 percent). The three-member family was 
TABLE 22

EDUCATION LEVEL OF FAMILY HEAD

\begin{tabular}{lcc}
\hline & $\mathrm{N}$ & $\%$ \\
\hline Education Level & 150 & 36.95 \\
\hline College & 130 & 32.02 \\
High School & 68 & 16.75 \\
No Response & 36 & 8.86 \\
Graduate + & 22 & 5.42 \\
Elementary & 406 & 100.00 \\
Totals & & \\
\hline
\end{tabular}

third with 16 percent reporting this as their family size, as shown in table 23.

Question twenty-three related to the respondents' age, sex, and interest in vegetarianism. The findings showed: ( I) the largest age group as 23-34 years old; (2) female respondents comprising 71 percent of the total sample; and (3) vegetarianism as a ninimal segment, approximately 13 percent of the total population surveyed.

Lastly, the interviewer inquired as to whether the respondents had ever eaten in a natural foods restaurant. Thirty percent stated they had aten in this type of food service while 65 percent said no. Five percent did not reply. 
TABLE 23

FAMIIY SIZE

\begin{tabular}{|c|c|c|}
\hline Size & $\mathrm{N}$ & $\%$ \\
\hline No Response & 36 & 8.87 \\
\hline$\therefore$ & 35 & 8.62 \\
\hline 2 & 108 & 26.60 \\
\hline 3 & 64 & 15.76 \\
\hline 4 & 78 & 19.21 \\
\hline 5 & 46 & 11.33 \\
\hline 6 & 18 & 4.43 \\
\hline 7 & 9 & 2.22 \\
\hline 8 & 4 & .99 \\
\hline 9 & 8 & 1.97 \\
\hline Totals & 406 & 100.00 \\
\hline
\end{tabular}

The writer has made observations and assumptions based on the findings of the questionnaire.

\section{Discussion}

Findings indicated that the majority of the interviewees enjoyed eating out and that 74 percent of them had aten out within the week prior to the survey. There did not appeax to be any particular occasion to prompt their behavior. 
It was a.lso found that two in a party was the most common grouping for diners; a trend which is reflected nationally (Eagen \& Cingolani, 1977). In fact, categories of two-, three-, and four-party groups accounted for 77 percent of the total sample in this study.

The dining/lounge type restaurant was most often patronized according to the respondents, while fast food and family style restaurants rated second as a choice of eating establishments. Only a small percentage chose cafeteria style. This may be due in part to the limited number of such services in the Pri-City area.

The average cost per meal for all those dining out was $\$ 4.27$ per person. When the researcher calculated the total amount spent by those eating out, 1,420 persons in all, it came to $\$ 6,062$ for a one month period of time. The major portion of this sum was spent in one week.

Fighty percent of those dining out indicated that they patronized familiar restaurants as returning customers, whereas. seventeen percent apparently went to the reported restaurant for the first time.

The data showed that 58 percent of those interviewed traveled three miles or less to eat out. In addition, 30 percent of those dining out stated they had traveled five to ten miles. Only a small number ( 9 percent) reported they had eaten more than ten miles from home. Some of these indicated that this was while they were traveling.

In spite of the fact that 56 percent of those interviewed 
(question eleven) stated that they would be willing to travel over ten miles to a restaurant of their choice; actual behavior, as shown in table 14 , does not bear this out.

The data results seemed to infer that the majority of respondents ( 84 percent) did not choose to try new foods when dining out but prefered the "old and tried." This could be a significant factor in reference to the establjishment of a (new concept) natural foods restaurant.

Quality of food was the feature considered by far most important for an eating place according to this study. Service was mentioned by 20 percent, and atmosphere was next in importance. Price and location seemed to be of least concern to those interviewed.

American food was listed as the favorite with Chinese a close second. Mexican and Italian food were third and fourth choices of the respondents.

Trirteen percent of the people interviewed in the TriCities did not perceive a need for more restaurants in the area. An additional 25 percent did not respond to the question (number fifteen). On the other hand, 17 percent wanted more fine dining facilities and 13 percent suggested the need for more family-type restaurants. A small percent (4.4) mentioned the need for a natural foods restaurant. Responses were spontarieous and not prompted by the interviewer.

When asked specifically if they would patronize a natural foods restaurant if food and service were of excellent quality, 
date. There appears to be a fairly even distribution of diningout activity for categories of the population studied.

TABLE 24

COMPILATION OF DEMOGRAPHIC DATA FOR

A SELECT GROUP OF TRI-CITY RESIDENTS

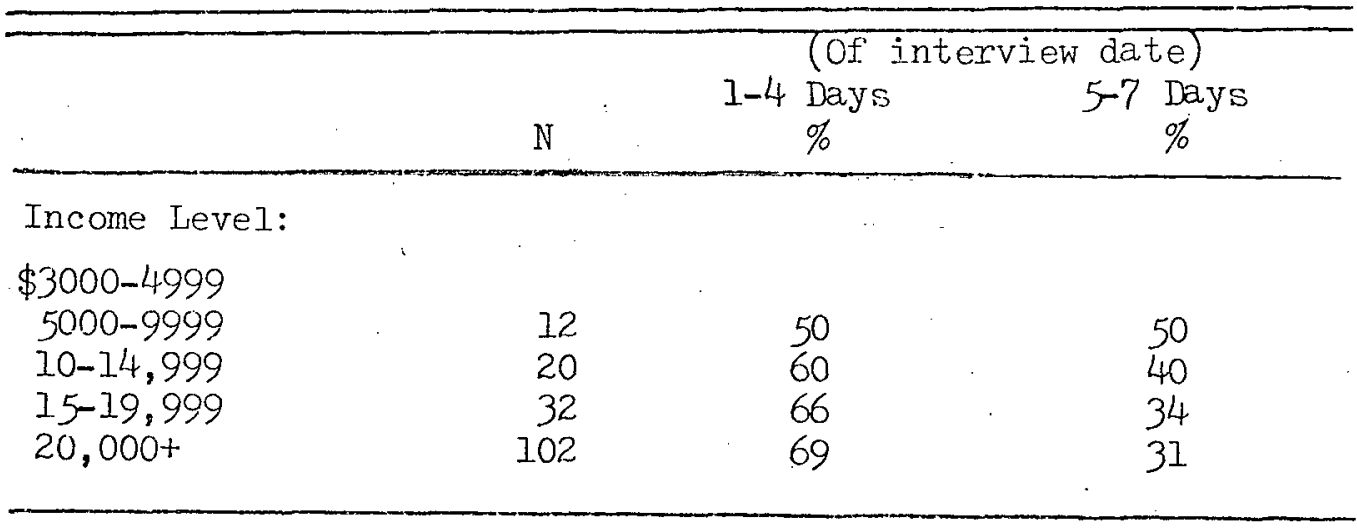

Educational Level:

Elementary

High School

College

Graduate

Family Size:
30

81

51

54

38

15

3

3
70

64

67

57
30

36

33

43

7

Family size:

1
2
3
4
5
6
7
8
9

Age:

\begin{tabular}{llll}
$22-24$ & 13 & 76 & 23 \\
$25-34$ & 74 & 65 & 35 \\
$35-44$ & 65 & 68 & 32 \\
$45-54$ & 49 & 63 & 37 \\
$55-64$ & 32 & 63 & 38 \\
\hline
\end{tabular}




\section{CHAPTER V}

\section{CONCLUSIONS}

It was the thesis of this study to deternine the feasibility of developing a natural foods restaurant in Tri-Cities, Washington. The survey research method was used to discover the attitude of: area residents toward such a restaurant. The conclusions made are based on the findings of this research.

The results showed that the Iri-Cities has a populace that enjoys eating out. The area appeared to have the ability to support another restaurant based on the formula of one for every 575 persons nationaliy. The area residents expressed an interest in patronizing a fine dining and/or speciality restaurant on a regular basis if the food and service were of high quality.

It was found that the average age, income level, and educational status of the Tri-City family heads compared favorably to national categories for highest food expenditure outside the nome. It was noted there was a high dining-out rate for all ages anỏ incorne levels of Tri-City residents.

The researcher calculated that based on the current TriCity population $(75,331)$, the frequency of dining out (58 percent eat out at laist once a week), with an average per meal expenditure of $\$ 4.27$ per customer, each existing restaurant ( 146 in al1) could potentially realize a sales volume of $\$ 66,404$ per year. 
( 59 percent of population $x \$ 4.27$ divided by $146=\$ 1,277$ per week.)

Of positive import for the natural. foods concept was the percentage of vegetarians in the sample studied--13 percent. If this percentage was representative of the total population, there could be approximately 9,793 vegetarians in the Tri-Cities. It could be assumed that persons with this type of diet pattern would patronize a natural foods restaurant at loast part of the time.

Another significant factor for the natural foods restaurant concept was the finding that 74 percent of all persons interviewed stated they would patronize. such a restaurant. In fact, 30 percent of all those interviewed indicated they had actually patronized a natural foods restaurant. (Thirty percent of the total Tri-City population would be 22,599 persons.) The study showed 4.4 percent suggested a need for this type of restaurant in the Tri-Cities.

The data implied that a restaurant serving familiar American or Chinese foods would be highly acceptable to most TriCitians, but to be well patronized it should be located within a three mile radius of the more densely populated areas. The inference was drawn from the findings that it would be well to incorporate a predominance of seating arrangements for two persons with flexibility to accommodate four to six.

A significant factor was the high ranking given foods in their natural state such as fresh fruit salads, fresh vegetable 
salads, homemade soups, and fresh baked breads. This ranking suggested that such iteris be offered on a continuous basis. However, most interviewees indicated that they would prefer to have this type of food served along with the normal restaurant fare rather than having a restaurant specialize in strictly natural foods. The very low rank given vegetarian entrees suggested unfamiliarity with the product and indicated that the introduction of such items into the menu should be done with caution.

It appeared to this researcher that there was one important implication in this study that should be taken as a caution in so far as a natural foods restaurant is concemed. The study found the residents showed a high patronage of dining/lounge type restaurants which seemed to infer a preference for alcoholic beverages as an accompaniment to the meal. Since this service is not typically provided by a natural foods restaurant, it could be assumed that this would prove a deterrent to sales. This researcher concluded from the evidence found in this study that a natural foods restaurant would succeed in the TriCities if the locale, service, and menu were in accordance with the findings of this study. Further, the findings suggested that a bakery in connection with such a restaurant that would provide a variety of fresh baked breads for the restaurant itself and on a take-home basis for the customers could be considered. 
APPENDIX 
APPENDIX A

INSTRUCTIONS FOR THE INTERVIEWER

I appreciate your willingness to assist with this telephone survey. It is part of a study being conducted in the TriCities to determine the feasibility of establishing a natural foods restaurant. The results of this survey will be very important to the decision.

It is important that you use the introduction as written and that you read the questions exactly as they appear on the questionnajxe so as to standardize the interviewing. process as much as possible. This is vital to the validity of the instrument.

If you have any questions regarding any part of the questiornaire or the responses you are receiving--please call me, Millie Kurtz at 545-9272 any time. It is important that we clear up any problems before we get too far into the survey.

I have given you a list of telephone numbers that have been randomly selected, so that no one knows the individuals to be interviewed. It is important that you stress that. You will call and interview 25 of these numbers. When you have completed the 25 interviews, you are through. Remember to put the telephone number at the top of each sheet and the date of the interview. If there is no answer or the Iine is busy, you may either go back to that number later or go on to the next one. Please remember to put the telephone number on each questioninaire. Please write in pencil. 
I would like the survey completed by the 20 th of November and will plan to pick up the results the 20th or the 2lst. If you will be away those days, please call me so that I may pick up the material earlier. Please note question \#7--do not mention tips if they ate at a fast food restaurant or cafeteria--do not mention liquor unless they indicated they ate at a restaurant with lounge. You may have to repeat the items in questions 13 and 16 more than once, or you may suggest they jot the items down for case of selection.

Thank you so much for your help! 
AFPENDIX B

INTFODUCTORY REMARKS

"Hello." (If child answers telephone, ask for parent.) (Teenager may be interviewed if no other adult is available.)

"A group of local business persons are interested in establishing a specialty restaurant in the Tri-Cities and is conducting a telephone survey of some of the residents to determine eating-out habits and food preferences.

"Would you be willing to take a few minutes to answer a few questions? Thank you so much!

"First of all, I would like to say that your telephone number was randomly selected so your name and address are unknom to me-your answers will be anonymous. Now, this is how we will do it:

"I will read each question as quickly and as distinctly as possible and thein pause for your answers. If you do not understand the question, please feel free to ask for clarification because we want this survey to be as accurate as possible. "You might want to get a paper and pencil to jot down a few notes as we go along.

"O.X. Are you ready to begin?

"Question number one ..." 


\section{$\triangle P P E N D I X \quad C$}

NATURAL FOODS RESTAURANT SURVEY

Date:

Telephone No.

1. Do you enjoy eating out?
(1) Yes,
(2) No,
(3) Can't afford,
(4) Other

2. How often do you eat out?

(1) Once a week, (2) Once a month, (3) More than once a week, (4) More than once a month, (5) Less than once a month.

3. When did you eat out last?
(1) 1-4 days, (2) 5-7 days,
(4) Over two weeks.
(3) 8-..24 days,

4. What was the occasion?
(I) Birthday,
(2) Anniversary,
(3) None; (4) Other

5. How many persons were in your party?
(1) 1 ,
(2) 2 ,
(3) 3 ,
(4) 4 ,
(5) 5

6. What type of eating place did you patronize?
(1) Fast food,
(2) Cafeteria,
(3) Family-served,
(4) Dining/Jounge,
(5) Specialty,
(6) Other

7. What was the approximate cost of meal for the entire group? (Excluding tips and liquor.)

8. Have you eaten thexe before?
(1) Yes,
(2) No

9. Approxinately how far is this ating place from your home?
(1) Less than I mile,
(2) I mile,
(3) 2 miles,
(4) 3 miles, (5) 4 miles,
(6) 5-10 miles,
(7) Over 10 miles 
10. Did you travel to this location specifically to eat out?
(1) Yes,
(2) No

11. How far would you be willing to travel for a good meal? (Ixc. of entertainment)
(1) Urder 5 miles,
(4) 1.5-19 miles,
(2) 5-9 miles,
(3) 10-14 miles,
(6) Over 25 miles

12. Did you order any foods that were new to you?
(1) Yes,
(2) $\mathrm{No}$

13. Which of the following features do you think is most important for an ating place?
(1) Atmosphere
(2) Service
(3) Quality of food
(4) Quantity of food
(5) Location
(6) Price
(7) Items 1-3
(8) Items 2 \& 3
(9) Other

14. Which of the following ethnic foods is your favorite?
(1) Italian
(2) Mexican
(3) Chinese
(4) American
(5) German
(6) Polynesjan
(7) $1-4$
(8) $2-3$
(9) Other

15. In your opinion, what type of eating place is most needed in Tri-Cities?

16. Would you patronize a natural foods restaurant in this area that served the following items: (if food and service were excellent quality)
(1) Yes
(2) No
(3) Probably
(1) Fresh fruit salads
(2) Firesh vegetable salads
(3) Quj.ck-cooked vegetables
(4) Honemade soup
(5) Fresh baked bread

(4) Maybe

(5) Don't know

(6) Other

(6) Frozen yogurt desserts

(7) Vegetarian entrees

(8) Vegetarian sandwiches

(9) Crepes (i.e. lettuce/tomato/ sprouts) 


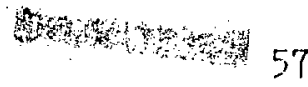

17. Now I/I read the list again and I would like you to indicate your:
(1) Ist choice
(2) 2nd choice
(3) 3rd choice

18. Which would you prefer?

(1) A restaurant that served all of the above foods。

(2) A restaurant that served a limited selection of the above along with regular fare.

FOLLOW ING PERSONAL QUESTTONS ARE IMPORTANT TO STUDY BUT NOT REQUIRED TO ANSWER.

19. Age of family head?

20. Average yearly family income?

21. Last grade level a.ttended by family head?

(I) Elementary

(2) High school

(3) College

(4) Graduate t.

22. Number in family: $1,2,3,4,5,6,7,8,9$

23. Respondent's age:

Respondent's sex:
Vegetarian:
(1) Yes,
(2) No,
(3) Partly

24. Are there other family members that are vegetarian?
(I) Yes,
(2) No,
(3) Not applicable

25. Have you ever eaten in a natural foods restaurant?
(1) Yes,
(2) $\mathrm{No}$ 
Frefix Identification:

Kennewick: $582,586,783$

Pasco: $545-547$

Richland: 942, 943, 945, 946, 947, 948, 967

\begin{tabular}{|c|c|c|c|c|c|}
\hline 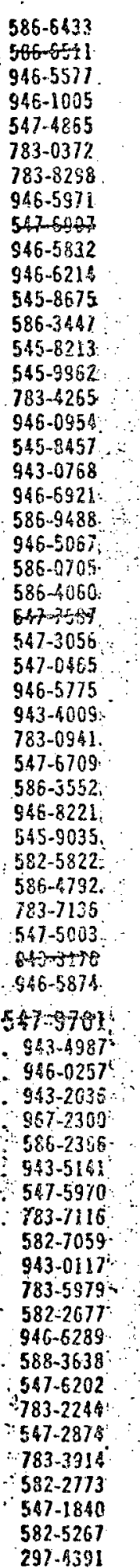 & $\begin{array}{l}547-6312 \\
547-6370 \\
783-9010 \\
582-3235 \\
582-2809 \\
983-5582 \\
783-8020 \\
586-9941 \\
582-5896 \\
943-4380 \\
586-4583 \\
946-1172 \\
946-5504 \\
\\
943-0319 \\
943-3267 \\
946-5390 \\
957-2498 \\
547-0856 \\
943-3422 \\
783-9316 \\
946-8712 \\
946-9142 \\
946-8139 \\
946-9865 \\
943-9362 \\
783-8897 \\
545-1991 \\
547-8943 \\
946-5742 \\
547-3112 \\
582-3483 \\
528-3801 \\
933-4378 \\
943-3290 \\
943-2071 \\
582-5573 \\
547-0638 \\
343-4148 \\
582-8350 \\
943-0196 \\
582-3372 \\
783-2573 \\
783-1213 \\
582-2423 \\
586-1211 \\
943-3558 \\
943-1612 \\
783-1610 \\
547-5401 \\
946-4851 \\
547-9625 \\
588-3091 \\
943-3973 \\
547-8734 \\
943-1328 \\
588-3708 \\
967-2121 \\
\end{array}$ & $\begin{array}{l}946+307 \\
588-3203 \\
547-1225 \\
582-3178 \\
545-1538 \\
545-8058 \\
547-3136 \\
783-4828 \\
943-1441 \\
943-3410 \\
946-1346 \\
946-8681 \\
783-3575 \\
943-4424 \\
783-5359 \\
586-6615 \\
582-2724 \\
943-0534 \\
547-4473 \\
946-0357 \\
948-3458 \\
547-4416 \\
946-4497 \\
586-4827 \\
547-4473 \\
9946-0277 \\
582-7945 \\
783-0468 \\
943-5549 \\
943-9496 \\
547-6145 \\
946-9546 \\
783-2635 \\
943-2274 \\
547-6911\end{array}$ & 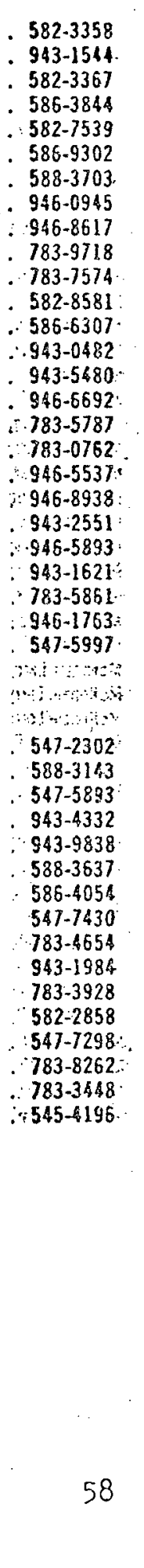 & 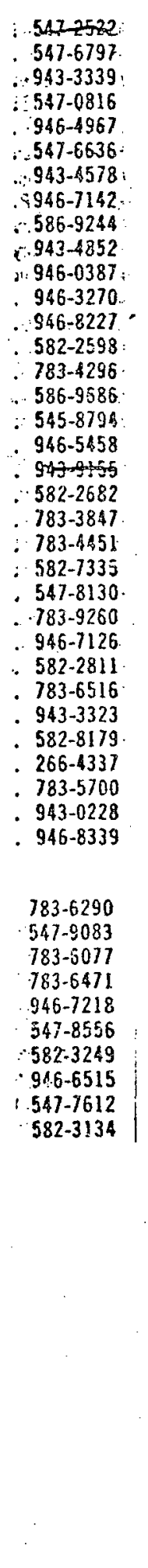 & 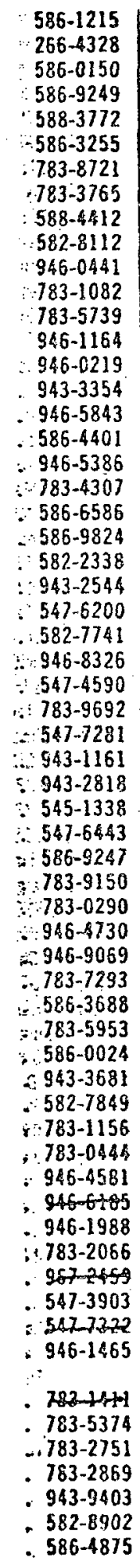 \\
\hline
\end{tabular}




\section{APPENDIX E}

\section{TRI-CITY RESTAURANT DIRECTORY}

\section{Restourants $\therefore$ : $\because$ mos \\ A-K's Sea Galleny $\quad \because 3 \%$ Ma}

A- Richland 500 Geo Wash Wy Richland -943-0396 7401 W Canal Dr Kenrewick $-783-9008$

2 A \& W Family Restaurant

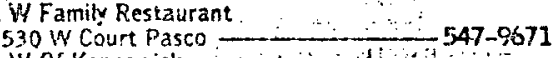

3 A \& W Of Kenrewick

2521 W Kennewick Av Xennewick _ 586-604s

4 A\&W Of Richtand

$4.913-0927$
5 Adrian's 924 Geo Wash Wy Richland $\quad 946-1322$

5 Adrian's 924 Geo Wash Wy Richland _ $\$$ 943-0927
$546-1322$

6 Alackan Burger Hut 2009 W Ccurt Pasco _... 545-9822

7 Arcti Circle Drive In

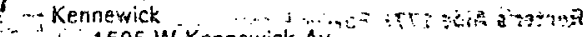
1505 W Kennewick AV Kernewick

$-585-4030$ Richland 255 Williams Blvd Richiand_ $946-6762$

8 Arsia Cafe Kwy 12 Richiand

9. BMLGOMS 8300 Gage Blud Kennewick - 783-5144

10 Bar-X Lodoe Restaurant $2 \% 12$ W Irving Pasco $i$

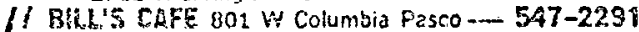

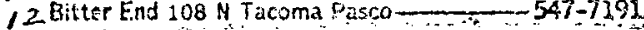

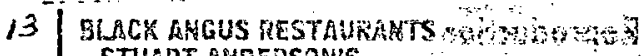
STUART ARTERSOA'S

1800 w lèys Pasco

if Erass Door the

707 Ceo Wash Wy Richland _ Preadox Bakery \& Sandwicis Shop The
1010 Jadwin Av Richland

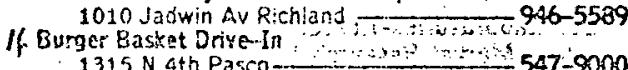

17 Burger King 2820 W Clearwater Av Kenncwick ____ 735-1701

18 BUTCHER BAKER CATDLESTIGH MAKER $2800 \mathrm{~W}$ Cleariater Av Kennewick - 783-7346

19 Cedars Pier 1

7 Clover Isiand Kannewick

i. $\{:$ (Please See Advertisement Page 179)

ZOCHAPTER ELEVER -...........

3311 W Ciearw3ter. Av Kennewick - 783-7433

(Please See Advertisemerit Page 180)

alchef Courmet is loth \& W hovis Pasco-

2 CHICO'S PIZZA

$3300 \mathrm{~W}$ Clnanvater Av Kennewick _ 783-8193

23 CMHESE GARDSNS

Restaurant 1520 No ath Pasco $2 . . . .154-0092$

- Dragon Rm $1520 \mathrm{~N}$ 4th Pasco . . 547-8632 24 Cin-Der Sub (Please See Advertisement This Page)

710 The Parkway Richland - $496-4529$

a City Cate \& Tumbicineen Rosm

200 Oivision benton. Row $583-3624$

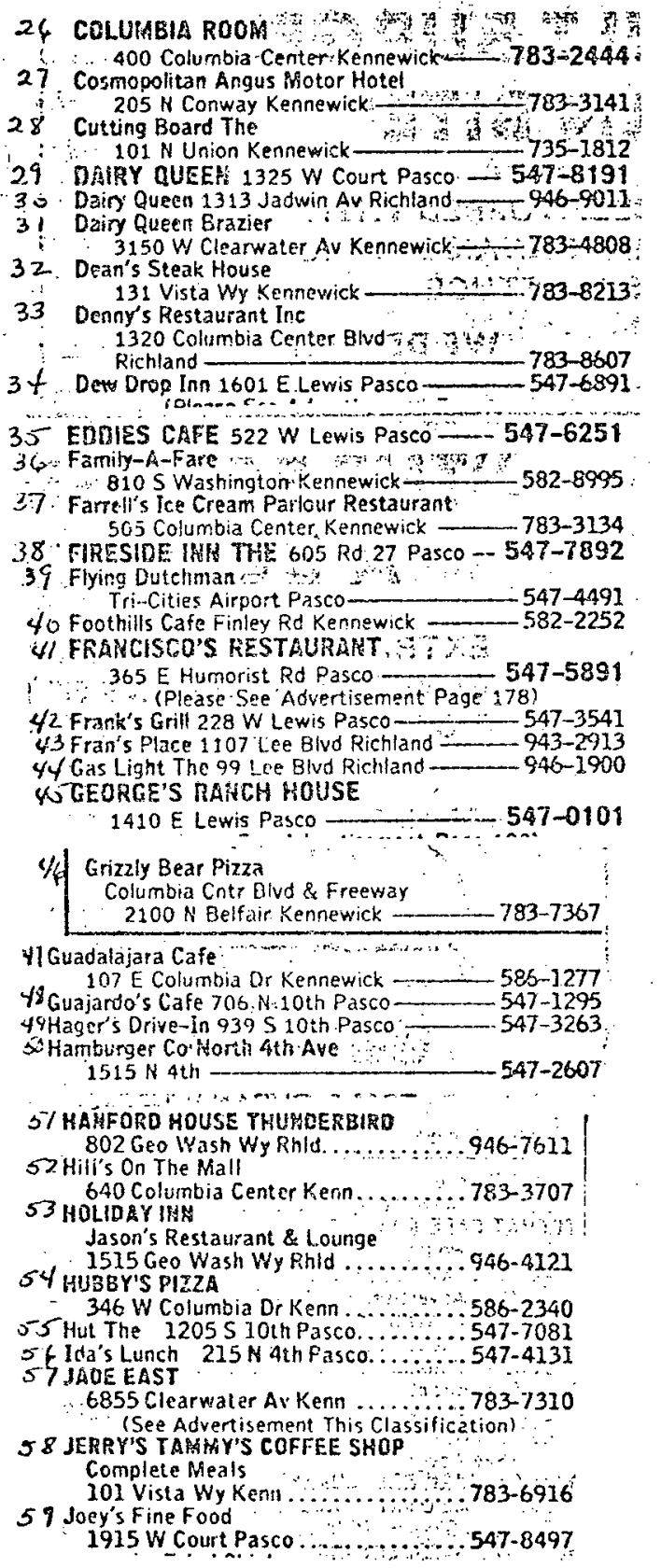


KEHTUCKY FRIEO CHICKEA

60 2631 W Kennewick Av Kenn ....... 582-8811 6! 2045 W Court Pasco ............... 547-8825 42.234 Symans Blud Rhld ............946-7974

LS KEYSTUME PIZZA OF RICHILAHD

See Our Ad Under Pizza

1524 Jadwin Av Rhld ............943-0677

6. 4 KINGS TABLE RIVERSHORE

50 Comstork Rhld .................946-5188 See Advertisement This Classification

\section{WS.LE'S TAMITIAM}

1342 Jadwin Av Rhld ............946-1068 (See Adverisement This Classification

66 Lepeti: Restaurant

3892 W Van Giesen W Rhid........ 967-2905

67 Mardene Ins 1776 Fowler RhId.......735-1801

68 Max's Broiler 24 Vista Wy Kenn......78 783-6713

69 MeDonald's Restaurant

$2202 W /$ Court Pasco.

MeEonatd's Restadr ants

Offiee

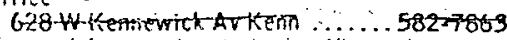

70 Kennewick

2541 W Kennewick AvKenn ...... 582-8685

71: Richland

325 Torbet! ohld i 946-4061

72 Mr Lee's 1034 Lee Bivd Rhld. .......9946-4314

73 BOOR PALACE

Chinese \& American Food $\quad 943-0685$

(See Advertisement This Classification)

24 Nortt 4th Ave Hamburger Co

$1515 \mathrm{~N}$ 4th Pasco $\ldots \ldots \ldots \ldots \ldots \ldots . . . \ldots 57-2607$

75 o'tenry's 21 20 S Auburn Kenn........ 586-3604

74. Orange Jutius

511 Columbia Center Kenn ........783-6416

7? PERKIAS CAKE \& STEAK

1185 Geo Wash W/y Rhld ...........9943-3349

Pizza Hut Highland Cntr Kenn ....783-9350

78 1923 W Court Pasco

791312 leet Blud Richland.........946-9221

8O PIZZA FETE

Richland

1045 Geo Wash Wy Rhld ..........946-3336

(See Acverisement This Classification)

81 Pizza Pete 2230.W Court Pasco..... 545-1091

82 PIZZA IUEST

3320 W Kennewick Av Kenn ........783-2425

(See Advertisement This Classification).

83 Port Ciate

Big Pasco Industrial Park Pasco ..... 547-6141

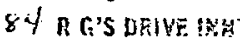

$$
\begin{aligned}
& \text { Hisme of The Deep Fried Mushrooms } \\
& \because \quad \text { \& } R \text { 's Special Hamburger With } \\
& \therefore \quad \text { Ham, Chease, Egg \& All The Extras! }
\end{aligned}
$$

Jo12 N Ejison Kenn. . . . . . 783-2660

85 Rafael's $219 \mathrm{~N}$ Date Kenn ........ $x=. .586-4274$

86. Raintree Restaurant

114 W Coiumbia Dr Kenn a $536-3534$

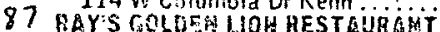

1353600 Wash Wy Rhld $\ldots \ldots \ldots . .946-0606$ (See Advertisement This Classification)

88 RED LIEN HGTOR IAN-PASEO

2525 N 20th Pasco

89 Red Robin Burgers \& Booze Emporium

13 ir Huntirigion Kenn...........735-2772

90 RIB PIT 335 W Columbia Dr Kern ..... 586-6494 (See Advertisement This Classification) - .

41 Roy's Chucti wagon of Pasco

$1325 \mathrm{~N} 20 \mathrm{~h}$ fasco .

1007 Wrighe Av Rhld.............. 943-1189 (See Advertisement This Classification!

93 RUB'S CHIKESE PALACE

1734 N 5 ih Pasco ...............547-4111

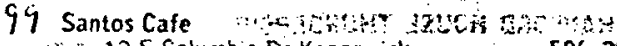
12. E Columbia Dr Kennewick - 586-3985

foo Satellite Restaurant \& Cocktail Lounge $\ldots$ $2 \mathrm{~N}$ Washington Kennewick -

101 SCIPATAR RESTAURAHT

$547-0711$

$\therefore$.W Lewis \& Ro 28 S Pasco

$547-4222$

102 Shakcy's Pizza Parior

707 W Court Pasco

103 SHRIMP BOAT THE

530 W Columbia Dr Kennexick —_ 586-3994 (Please See Advertisement This Page)

joy Sizzler Fanily Steak House

3200 W Clearwater A. Kennewick 783-7445

105 SHIPDER'S FISH'W CHIPS CHOWDER

HOUSE ....

2226 W Court Pasco

106. 1028 Lee Blvd Richland —— (Please See Advertisement Page 179) ....

107 SMITTY'S PANCAKE HOUSE

712 W-Lewis Pasco-

108 Spaghetti Establishment The

2107 W 4th Ay Kerneysick _ $596-620$

1... (Please See Advertisement Page 178)

- 13. W Lewis \& N 14t5 Pasco $547-8242$

Wi, ... (Please See-Adverkisement Page 178)

110 Spudnut Shop $130 \mathrm{~N} 10 \mathrm{th}$ Pasco - 547-8862

ill Starite Restaurant \& Lourige

927 Columbia De 58 Richtand $783-2811$

112 Steak-Out The

213 W Kennewick Av Kennewick a... 502-5048

(13, T J's Pantry \& Lounge

Kennewick $\because$ Le 3013 W Clearwater Av ${ }^{\prime} a$ s

Kennewick - 7230-0233

114 Richland

1435 Geo Wash Yyy Richland _-_ _ _ 945-8706

115 Taco John's 1819 W Court Pasco ___ _ 545-9285

ite Taco John's

701 Vineyard Dr Keanewick ___ 586-2964

IIT Taco Spot The 1411 if 4th Pasco - 545-1081 118 Taco Time (Please Sae Advertisement Page 177 )

Kennewick 306 N Nurain - - .

119 Richland 894 Stevens Qr Richland -

120Tammy's Coffee Shop $\quad: \quad y_{1}, a_{2}=\cdots$ 1314 Jadwin Av Fechlond _ 1063

12i Tastee-Freez Drive I 895 Stevens Dr Richland _

122 TASTEE FREEZE 1501 W Sylvester Pasco__ 507-7152 (Please See Advertisement Page 178)

123TAYLOR HAID 524 3d Pasco-_ 587-6833

124 TOPHAT CAFE \& LOWHGE ..., .

1... $\therefore 404$ W. Lewis Pasce ___ 547-7341 (Please See Sdyartisement This Page)

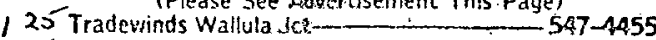

126 TRIPLE XXX ROOT EXER DRIVE IN 1008 W Columbie Pasco____ 547.8022 3 (Please See ddvartisement: Page 279)

127 Vincenis' 829 Goethas ar Richiand $243-2617$ 128 VIP's Restaurants

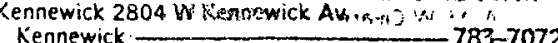

\begin{tabular}{l}
29 \\
0.627 Jadivin Av Richload ___ _ _ _ \\
\hline
\end{tabular}

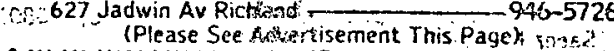

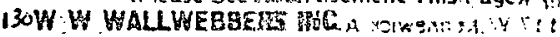
1100 Jadwin Riridasd _- 949-4565

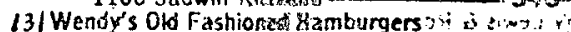

2511 w Court Pasro

132. Wendy's Old Fashioned Hamburgers in 3115 W Clearwate Ay Kennewict $\div-\cdots 303-558$

133 Wolfics Hanford Av Agrton City —_- 5325090

134WW SKYPARK RESTOLRANT

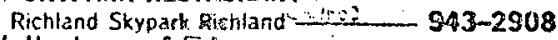

(1) Zip's Hamburgers \& 5 rist Kennewick

400 E Columbix Cr Kennewick _- 582-18800

13: Richland 1556 Fowter Richland

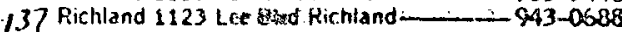


BIBLTOGRAPHY

\section{$\underline{\text { Periodicals }}$}

Blackwell, Roger. "Directions for the $80^{\prime} \mathrm{s} . "$ The Missouri. Restaurant, 61 (February, 1977):16.

Germain, Fred. "Watural Food Eateries Sprouting Errotic Blossoms, Not Weeds." Nation's Restaurant News, 6 (July 3, 1972):9.

"Health Food Restaurant Serves Beer, Wine to Perk up Natural F'are." Nation's Restaurant New: 10 (JuJy 19, 1976):7.

Morel, J.J. "Don't Neglect the Vegetarian." Hotel and Catering Review, (March, 1973): 44 .

Nichol, F. D. "Iet's Take a New Look s.t Vegetarianism." Review and Hersld, Special Printing, February, 1966, p. 1

Shafer, Robert B. "Factors Affecting Food Behavior and the Quality of Husbands and Wives Diets." Journal of American Dietetics Association, 72 (February, 1978):138.

Shaw, Nadine. "Health Food Operators Work Both Sides of Eating Street." Nation's Restaurant News, 6 (May 22, 1972):10.

Soller, Patricia. "What's New? 'Healthy' Foods." Restaurant Business, 75 (September, 1976):133.

Stephenson, Lloyd. "The President." The Missouri Restaurant, 61. (February, 1977): 4 .

Vandewater, Bob. "Greentrees' Juice Factory Jousts with Giants." Nation's Restaurant News, 10 (January 5, 1976):33.

"The Vegans Are Here (To Stay)." Food Management, 11 (July, 1976): 49.

Weiss, F. B. "Less Haughty Haute Cuisine." Restaurant Pusiness, 70 (October 1, 1971):44.

Books

Clark, Lincoln H. "Research On Consumer Reactions." Consumer Behavior. Vol. III. New York: Harper. Brothers, 1958, p. 29. 
Kroc, R., and Anderson, R. Grinding It Out: The Making of McDonalds. Chicago: Henry Regnery Company, 1977, p. 192.

Newspapers

Ios Angeles Times. "Vegetarianism Gains Popularity on Campus." October 24, 1971, Section 10-C.

Tri-City Herald. "The Boom Continues." January I, 1978.

Tri-City Herald. "Progress Report." April 9, 1978.

\section{Reports}

Bureau of the Census. U.S.A. Statistics in Brief. Washington: U.S. Government Printing office, 1977.

Eagan, Gloria, and Cingolani, Melodie. Restaurants and Food Service. A report prepared by the Bank of America. Vol. 12, No. 8, 1977.

Frost and Sullivan, Inc. The Health Foods and Nutritive Supplements Market in Europe. New York: 1976.

Population Enrollment and Economics Statistics Division. Washington State Informative Report-Forcast of Population by Age and Sex. Olympia, Washington: 1977.

Rogers, David S., and Green, Howard I. Changes in Consumer Food Expenditure Patterns. A report prepared by Green and Associates, Inc. Birmingham, Michjgan: April 1978.

Seejig, R. A. A Review of Vegetariarism. A report prepared for the United Fresh Fruit and Vegetable Association. Washington: March 1976 .

Small Business Administration. Restaurants and Catering, No. 17. A report prepared by the Education Division; Office of Management Assistance. Washington: U.S. Government Printing office, 1973.

Tri-Cities Chamber of Commerce. A Statistical Review. Tri-Cities, Washington: 1978.

U.S. Senate. Dietary Goals for the United States. A report prepared by the select Committee on Nutrition and Human Needs. Washington: U.S. Government Printing Office, February 1977.

Other Sources

Kurtz, Millie $M$. A Survey of Vegetarian Restaurants in the United States. A student project. Eastern Washington University, 1978. 